\title{
THE COVID-19 PANDEMIC - AN IMPEDIMENT IN PERFORMANCE OF CONTRACTS
}

\author{
Mohammed Zaheeruddin
}

Received: June 25, 2020 / Revised: September 30, 2020 / Accepted: November 18, 2020

(C) Association of Economists and Managers of the Balkans, 2020

\begin{abstract}
The COVID-19 pandemic has created unprecedented situation all over the world, compelled the governments to declare lockdown, closing of businesses, industries, commercial activities, ban on certain imports and exports. Under these circumstances, an obligor may not be able to perform his contractual obligations, consequently may result in breach of contract. In case of claim of damages by the obligee for breach of contract, the obligor may seek exemption from damages under the law of impediment or force majeure. According to Article 79 of the UN Convention on Contracts for the International Sale of Goods 1980 (CISG), a party is not liable for damages due to non-performance, delay or defect in performance, if he can prove that the failure was due to an impediment beyond his control. The COVID-19 situations are beyond the control of the parties to the contract, must be considered as an impediment or force majeure and the non-performing party is entitled for exemption from damages under Article 79 of CISG.
\end{abstract}

Keywords: COVID-19, UN CISG, Impediment, Force majeure, Damages.

\section{JEL Classification K12}

\section{$\triangle \quad$ Z_Mohammed@uaeu.ac.ae}

1 College of Law, United Arab Emirates University (UAEU), Al Ain, United Arab Emirates, P.O. Box No. 15551 


\section{INTRODUCTION}

The Corona Virus disease 2019 (COVID-19), designated as pandemic by the World Health Organization $^{2}$ devastating the whole world, death of hundreds of thousands of people, resulting lockdown of nations all over the world, closure of industries, manufacturing units, businesses places, stoppage of all kinds of transport, supply chain disruption, effect on imports, exports and loss of employment to the millions of people around the world.

COVID-19 situation continues to severely affect public health and cause unprecedented disruptions to economies and labour markets. ${ }^{3}$ Under these circumstances there has been continuous uncertainty in performance of contractual obligations by the parties in domestic as well as in international trade contracts. The COVID-19 situation and its consequences are outside the sphere of control of parties to the contract, may result in failure to perform contractual obligations and consequently result in breach of contract. In order to deal with such situations and to exempt a non -performing party from liabilities, national legislations recognized the rule of impossibility of performance of contract due to any reason beyond the control of a party to the contract. ${ }^{4}$

The object of this paper is to justify that the existing COVID-19 situation and its consequences constitute an impediment, outside the control of a parties to the contract and any non-performance of contractual obligations are entitled for exemption from damages under the United Nations Convention on Contracts for the International Sale of Goods 1980 (UN CISG) (Vienna Convention, 1980). In this regard reference has been made to some national legislation, with special focus on UN CISG and decided case law.

In common law systems rule of impossibility is known as doctrine of frustration of contract, and in civil law systems known as force majeure. The concept of force majeure is some kind of impracticability and generally refers to ,superior forces” or circumstances that are „,beyond the control and without the fault or negligence" of the non-performing obligor. ${ }^{5}$ The rule of exemption from damages due to the reason beyond the control of a party has been recognized under different national legislations and Article 79 of UN CISG.

\section{IMPEDIMENT RULE UNDER NATIONAL LAWS}

According to the United States Uniform Commercial Code (UCC), if there is non-delivery or delay in delivery of goods, in whole or in part by a seller, he is not in breach of his duty if the performance was not practicable due to occurrence of contingency events. ${ }^{6}$ Similarly, the German Civil Code (BGB) provides that a claim for performance is excluded to the extent that performance is impossible for the obligor or for any other person. ${ }^{\text {? }}$

\footnotetext{
2 http://www.euro.who.int/en/health-topics/health-emergencies/coronavirus-covid-19/news/news/2020/3/who-announces-covid-19-outbreak-a-pandemic.

3 https://www.ilo.org/wcmsp5/groups/public/dgreports/dcomm/documents/briefingnote/wcms_743146.pdf, last visited on 24 June 2020.

4 Section 2-615 of the United States Uniform Commercial Code (UCC); Section 275 (1) of German Civil Code (BGB); Article 1256 of the Italian Civil Code; Section 56 of the Indian Contract Act, 1872; Section 27 (1) of the Swedish Sale of Goods Act 1987; section 7 of the United Kingdom the Sale of Goods Act 1979.

$5 \quad$ Jennifer M. Bund (1998). Force Majeure Clause: Drafting advice for the CISG Practitioner, 17 J.L. \& Com., 381.

6 Section 2-615.

$7 \quad$ Section $275(1)$.
} 
According to the Italian Civil Code an obligation is extinguished when its performance becomes impossible for a cause not attributable to the obliged party. ${ }^{8}$ An obliged party who does not exactly perform the obligation due is liable for damages, unless he proves that the non-performance or delay was due to impossibility of performance for a cause not attributable to it. ${ }^{9}$

The Indian Contract Act, 1872 contains a rule that an agreement to do an act impossible in itself is void. If an act after the contract becomes impossible, becomes void when the act becomes impossible or unlawful. ${ }^{10}$ Similarly, in United Kingdom the Sale of Goods Act 1979 provides that where there is an agreement to sell specific goods and subsequently the goods, without any fault on the part of the seller or buyer, perish before the risk passes to the buyer, the agreement is avoided. ${ }^{11}$

The Swedish Sale of Goods Act 1987, provides that the buyer is entitled for damages for losses that he suffered because of the seller's delay in delivery, unless the seller able to prove that the delay was due to an impediment beyond his control. Further, the seller must prove that he could not reasonably be expected to have taken into account the impediment at the time of the conclusion of the contract and whose consequences he could not reasonably have avoided or overcome. ${ }^{12}$

The UNIDROIT Principles 2016 under the force majeure rule provides that the non-performance by a party is excused if that party establishes that the non-performance was due to an impediment beyond its control, it was not foreseeable at the time of concluding of contract and not avoidable it or its results. ${ }^{13}$ This rule is similar to impediment recognized in Article 79 of UN CISG.

The reference made to United States, German, Italian, Indian, Swedish national laws establish that a party is not liable for damages where the non-performance happens due to an impediment outside the control of obligor. Similarly, the parties to the international trade contracts governed by UN CISG may seek exemption from damages on the ground of "impediment" under Article 79.

\section{IMPEDIMENT UNDER UN CISG}

The UN CISG applies for the international sale of goods between the parties from different nationalities and when their respective States have ratified this Convention ${ }^{14}$ The general rule under UN CISG is that if the seller fails to perform any of his obligations under the contract or the Convention, the buyer may invoke rights provided in Articles 46 -52 CISG or claim damages as available in Articles 74-77. ${ }^{15}$ Similarly, if the buyer fails to perform any of his obligations under the contract, the seller may invoke rights provided in Articles 62-65 CISG or claim damages as recognized in Articles 74-77. ${ }^{16}$ However, if the failure was due to any impossibility (temporary or permanent), the obligor/promisor (seller/buyer) is not liable for damages under Article 79 CISG.

Article 79 (1) of CISG exempts the obligor from damages for his non-performance, for which he needs to establish following requirements: (1) the failure to perform was due to an impediment beyond his control; (2) the impediment was such that reasonably not expected to have taken into

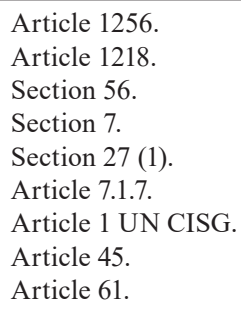


account at the time of conclusion of the contract; and (3) the impediment could not reasonably be expected to have avoided or overcome it or its consequences.

The other requirements are, party seeking exemption under article 79 clauses (1) or (2) must give notice of impediment and its effect to the other party, otherwise he will be liable for damages for non-performance of the contractual obligations. ${ }^{17}$ Article 79 exempts the obligor only from damages claim and not from the other remedies available to the non-breaching party. ${ }^{18}$ The exemption under Article 79 sub clauses (1) and (2) from damages is allowed to the non-performing party only during the period that impediment exists. ${ }^{19}$

\section{a. Exemption from damages:}

Article 79 CISG exemptions are available for non-performance or delayed performance of all or part of any of the obligor's obligations due to any impediment outside the control of promisor. ${ }^{20}$ The exemption under Article 79 bars claims for (specific) performance against the seller ${ }^{21}$ and once a party invokes article 79 the exemption remains in effect as long as the impediment exists. ${ }^{22}$

The exemption is available only from claiming damages; the obligee's rights other than damages remain open, ${ }^{23}$ such as request for renegotiation, adaptation of contract or termination of contract. It is not clear under Article 79 whether the exemption of the promisor extends to contractually agreed sums, i.e. liquidated damages and penalties. ${ }^{24}$ If there is possibility for a party to perform in part, such party should only be excused for the part of the contract it cannot perform and not from the whole obligations. ${ }^{25}$

\section{(i) Impediment was beyond the control of obligor:}

A party claiming exemption under Article 79 must establish that the failure was due to an unpredictable and unavoidable impediment, which lies beyond its sphere of control. ${ }^{26}$ If the disabling event falls within a seller's sphere of control, the seller will not be protected from liability. ${ }^{27}$

The impediment claiming by obligor must be unforeseeable and un-manageable risk or an exceptional event. ${ }^{28}$ Whether an impediment is un-manageable risk or totally exceptional event should be determined objectively from a reasonable obligor's view at the time the contract is to be performed. ${ }^{29}$

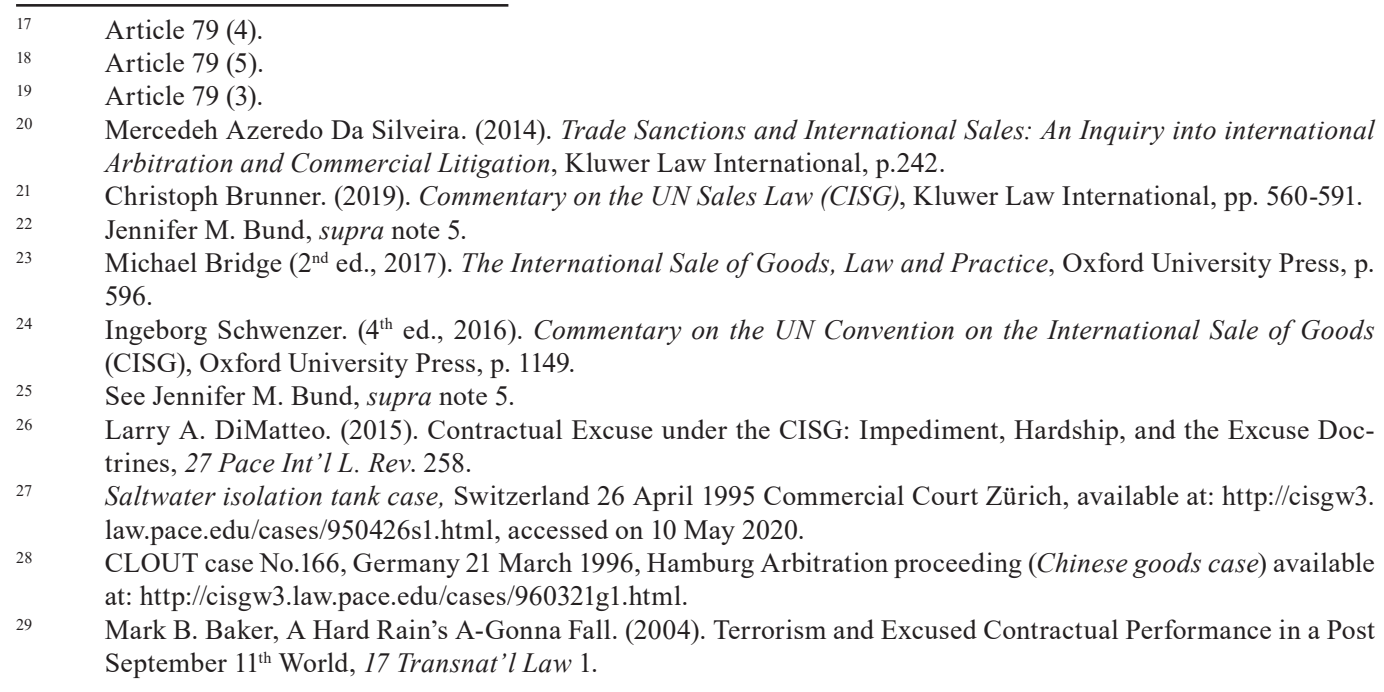


If the non-performance is due to impediment within the sphere of obligor, such as financial difficulty, mismanagement, the obligor is not entitled for exemption under Article 79. Among the few instances which fall outside the sphere of obligor are: a severe shortage of raw materials or supplies due to war, embargo, unforeseen shutdown of major sources of supply, ${ }^{30}$ general strike, ban on imports or exports or similar government restrictions.

\section{State Interventions}

The State interventions that prevent a party from performance of its contractual obligations are generally lies outside of the parties' sphere of control. ${ }^{31}$ In principle, it is required that the act of State effectively restricts the freedom of trade or payment, in particular, impedes the delivery of the goods. ${ }^{32}$ The examples for acts of State are government orders or laws banning of imports or exports, trade sanctions, embargoes, currency exchange restrictions. It remains uncertain whether a State-run or State-owned enterprise can invoke them for its exemption. ${ }^{33}$

In Bulgarian Chamber of Commerce and Industry (Coal case), ${ }^{34}$ the tribunal held that a prohibition on coal exports by the Ukraine Government and equal contribution to the harm by the seller and buyer may constitute an impediment within the meaning of article 79. Similarly, in National Oil Company v. Libyan Sun Oil Company, ${ }^{35}$ the tribunal held that banning imports of Libyan Oil into the US was an act of State, outside the control of a party and constitutes force majeure.

In Harriscom Svenska, AB v. Harris Corporation, ${ }^{36}$ the force majeure clause enabled a seller to avoid liability for non-performance of a contract due to governmental interference. In Caviar case ${ }^{37}$ the buyer unable to pay the purchase price to the seller due to the United Nations embargo against Yugoslavia. The arbitral court found that after lifting of the UN sanctions, the buyer was obliged to pay the purchase price to the seller with interest.

If the non-performance was due to any restrictions imposed by the State, the obligor can successfully invoke Article 79 for exemption, provided the impediment should not be present at the time the contract was concluded.

\section{Acts of God}

The acts of God sometimes make the performance impossible, such as earthquakes, floods, tsunami, plague, epidemic, pandemic. In cases of act of God, it will have to be carefully examined whether or not the natural phenomenon was foreseeable. ${ }^{38}$

\footnotetext{
Lisa M. Ryan. (1995). The convention on Contracts for the International Sale of Gods: Divergent interpretations, 4 Tul. J. Int'l \& Comp. L. 99.

See Schwenzer supra note 24 at 1137.

See Christoph Brunner, supra note 21 at 560-591.

See Schwenzer, supra note 24 at 1137.

Bulgaria 24 April 1996 Arbitration Case 56/1995, available at http://cisgw3.law.pace.edu/cases/960424bu.html, accessed on 24 June 2020.

Final Award on Force Majeure, 31 May 1985, YCA 1991 pp. 54 et seq., p. 61, n. 18.

$3 \mathrm{~F}$ ed 576 (1993).

Hungary 10 December 1996, Budapest Arbitration Proceedings, CISG-database, available at http://cisgw3.law. pace.edu/cases/961210h1.html.

$38 \quad$ See Schwenzer, supra note 24 at 1136.
} 
In Tradax Export SA v. Andre \& Cie $S A,{ }^{39}$ due to severe floods Mississippi valley in 1973, there was a domestic shortage of soya beans, therefore, the US Government announced embargo on export of soya beans. The court held that prohibition of export could also be a force majeure event and the seller in principle rely on the force majeure clause contained in the contracts, because they could not obtain goods of the contract description by exercise of any means reasonably open to them.

The other impossibilities are breakdown of transport, destruction of machinery, fire, explosion, general Strike, terrorist attack, warfare, armed conflicts, in some cases economic impossibility. In PPG Industries, Inc. v. Shell Oil Company, ${ }^{40}$ the seller Shell Company failed to perform the contract due to explosion and sought exemption under section 2-615 of UCC. The Fifth Circuit court affirmed the lower court decision and held that the Shell's performance was liable to be excused due to occurrence of contingency i.e. explosion.

\section{Economic impossibility}

A change of economic circumstances which is of such gravity that the procurement of the goods would cause the obligor to incur unreasonable costs in relation to the contract price, can justify for exemption under Article $79 .{ }^{41}$ For example in Scafom International BV v. Lorraine Tubes S.A.S, ${ }^{42}$ the Belgian Court of Cassation held that the impediment defined in Article 79(1) may include changed circumstances, such as economic hardship that made the performance difficult but not impossible. On appeal, the Belgium Supreme Court held that the unforeseen increase of $70 \%$ in the price certainly rise to a serious imbalance, therefore, buyer must renegotiate the contractual conditions.

\section{(ii) Impediment was not foreseeable:}

One of the important requirements under Article 79 (1) is that the non-performing party needs to establish that it could not reasonably be expected to have taken the impediment into account at the time the contract was concluded. ${ }^{43}$ An impediment is foreseeable if the obligor was aware of impediment at the time the contract was concluded. Foreseeability, avoidability, and the possibility of overcoming the impediment must be judged objectively by the standards of a reasonable person in the same situation. ${ }^{44}$

In CLOUT Case No. 104, ${ }^{45}$ the Bulgarian buyer failed to open a Letter of credit (LoC) in favour of Austrian seller and claimed that it was due to Bulgarian government order that suspended payment of foreign debts. The tribunal found that the government order was present at the time parties have concluded the contract, it was a foreseeable impediment, and therefore, the buyer committed a breach of contract.

If the non-performing party should have known of the circumstances of his disablement, Article 79 does not exempt from liability. In Malaysia Dairy Industries Pte. Ltd. v. Dairex Holland BV, ${ }^{46}$ the seller knew the restrictions in buyer's country at the time of concluding the (revised) agreement, therefore, such restrictions cannot be considered as force majeure.

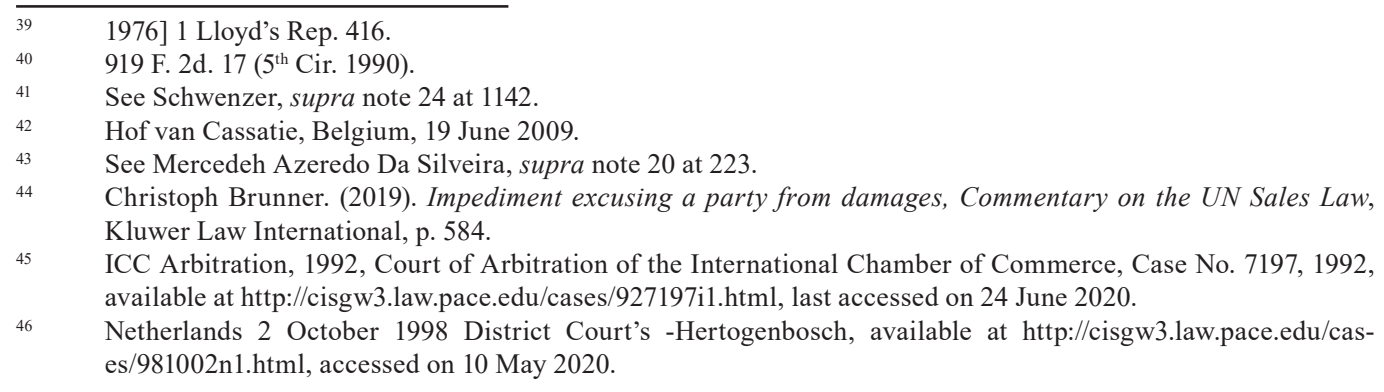


An impediment was avoidable, if the performance of contract is possible by alternate or substituted methods, like change of transport route, purchase material from other sources, making payment through alternate method.

\section{b. Conditions for seeking exemption due to failure of third parties:}

Article 79 exempts the obligor (seller or buyer) due to non-performance of third parties whom the obligor has engaged to perform the whole or part of the contract. ${ }^{47}$ An exemption in Article 79 (2) is possible if the grounds for the exemption cumulatively met by both the obligor himself and the third party.

Article 79(2) encompasses independent third parties who take over performance for the seller or buyer either entirely or in part on their own responsibility. ${ }^{48}$ The third parties may be carriers, shippers, banks, sub-contractors. In contract performance procurement of goods falls within the obligor's risk; therefore, sales representatives, suppliers and sub-suppliers are not third parties, within the meaning of Article 79 (2), as they do not perform independent obligations which the seller himself owes to the buyer. However, an exemption may be possible if the supplier has monopoly over business and seller has no other choice or source to procure the goods.

In Raw Materials, Inc. v. Manfred Forberich GmbH \& Co., $K G{ }^{49}$ the seller (Forberigh) failed to supply Russian railroad rail to the buyer (RMI) due to failure of its supplier and unable to ship because the port of St. Petersburg unexpectedly frozen. The defendant contended that the impediment was foreseeable and not entitled for exemption under UCC 2-615 which is similar to Article 79 of CISG. The District Court denied defendant's motion for summary judgment and held that Forberigh's non-performance was justified due to force majeure.

In cases where third parties are involved in supply or procurement, if the obligor would like to protect himself from damages due to the non-performance of his suppliers, he may do so by adding a clause in contract stating that his performance is subject to performance of supplier/s.

\section{c. Duration of exemption:}

The exemption provided under article 79 has effect for the period during which the impediments exists, ${ }^{50}$ once the impediment ceased to exist, in good faith the obligor must perform the contract, otherwise, he is liable for damages. The temporary impediment is considered as an extra time, granted for such performance and during impediment time the obligor's right to require performance or to claim damages is suspended. ${ }^{51}$

\section{d. Notice of impediment to the other party:}

The obligor who fails to perform his contractual obligations must give notice to the obligee of the details of impediment and its effect on his ability to perform the contract. ${ }^{52}$ If the obligor failed to serve notice to the obligee within a reasonable time, after he knew or ought to have known of the impediment, the obligor is liable for damages to the obligee for not providing notice of impediment.

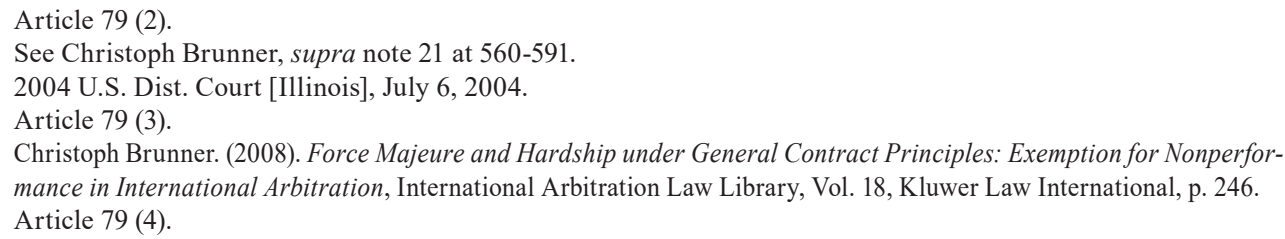




\section{e. Article 79 (1) \& (2) exempts only from damages:}

Article 79 CISG exempts the non-performing party only from damages; it does not prevent obligee from invoking any other right other than claiming damages. ${ }^{53}$ The obligee may resort for other remedies such as, grant extra time for performance, request for renegotiation of contractual terms and adaptation of contract or terminate the contract.

\section{f. Burden of Proof:}

The reading of Article 79 suggests that the party seeking exemption (obligor) must prove that the failure was due to an unforeseeable impediment which is beyond his control. For example, if a seller claims exemption from damages, he bears the burden of proof. ${ }^{54}$

In cases where the performance of the contract would involve a danger to life or health for the obligor or third parties, such circumstances can be considered as an impediment. If an internal disruption can be traced back to an external source, such as an epidemic illness of the entire personnel, a temporary exemption may be contemplated. ${ }^{55}$

\section{CONCLUSION}

The COVID-19 situation and its consequences are unprecedented; therefore, it needs to be considered as an impediment or force majeure and qualifies for exemption from damages under Article 79 of UN CISG or similar rule under national legislation. The COVID-19 situation was not foreseeable for the contracts entered before its spread and its affects are beyond the control of parties to the contract. The party seeking exemption from damages for its non-performance, delay or defect in performance due to COVID -19 situation required to prove that the impediment was beyond the control of an obligor, impediment was reasonably not foreseeable or avoidable or overcome it or its consequences. The parties to the contract for the domestic or international sale of goods avoid damages due to unforeseeable events, by including impediment or force majeure clause in contract.

\section{REFERENCES}

Christoph Brunner. (2008). Force Majeure and Hardship under General Contract Principles: Exemption for Non-performance in International Arbitration, International Arbitration Law Library, Vol. 18, Kluwer Law International, p. 246.

Christoph Brunner. (2019). Commentary on the UN Sales Law (CISG), Kluwer Law International, pp. 560-591.

Christoph Brunner. (2019). Impediment excusing a party from damages, Commentary on the UN Sales Law, Kluwer Law International, p. 584.

Ingeborg Schwenzer. $\left(4^{\text {th }}\right.$ ed., 2016). Commentary on the UN Convention on the International Sale of Goods (CISG), Oxford University Press, p. 1149.

Jennifer M. Bund (1998). Force Majeure Clause: Drafting advice for the CISG Practitioner, 17 J.L. \& Com. 381.

Larry A. DiMatteo. (2015). Contractual Excuse under the CISG: Impediment, Hardship, and the Excuse Doctrines, 27 Pace Int'l L. Rev. 258.

\footnotetext{
$53 \quad$ Article 79 (5).

$54 \quad$ CLOUT Case No. 596 Germany 2 February 2004, Germany 2 February 2004 Appellate Court Zweibrücken (Milling equipment case), available at: http://cisgw3.law.pace.edu/cases/040202g1.html.

$55 \quad$ See Christoph Brunner, supra note 44 at 564.
} 
Lisa M. Ryan. (1995). The convention on Contracts for the International Sale of Gods: Divergent interpretations, 4 Tul. J. Int'l \& Comp. L. 99.

Mark B. Baker, A Hard Rain's A-Gonna Fall. (2004). Terrorism and Excused Contractual Performance in a Post September $11^{\text {th }}$ World, 17 Transnat'l Law 1.

Mercedeh Azeredo Da Silveira. (2014). Trade Sanctions and International Sales: An Inquiry into international Arbitration and Commercial Litigation, Kluwer Law International, p.242.

Michael Bridge ( $2^{\text {nd }}$ ed., 2017). The International Sale of Goods, Law and Practice, Oxford University Press, p. 596.

\section{Cases:}

Bulgarian Chamber of Commerce and Industry (Coal case), Bulgaria, 24 April 1996 Arbitration Case 56/1995, available at: http://cisgw3.law.pace.edu/cases/960424bu.html.

Caviar case, Hungary 10 December 1996, Budapest Arbitration Proceedings, CISG-database, available at http://cisgw3.law.pace.edu/cases/961210h1.html.

CLOUT Case No. 104, ICC Arbitration, 1992, Court of Arbitration of the International Chamber of Commerce, Case No. 7197, 1992, available at http://cisgw3.law.pace.edu/cases/927197i1. html.

CLOUT case No.166, Germany 21 March 1996, Hamburg Arbitration proceeding (Chinese goods case) available at: http://cisgw3.law.pace.edu/cases/960321g1.html.

CLOUT Case No. 596 Germany 2 February 2004, Germany 2 February 2004 Appellate Court Zweibrücken (Milling equipment case), available at: http://cisgw3.law.pace.edu/cases/040202g1.html.

Harriscom Svenska, AB v. Harris Corporation, 3 F ed 576 (1993).

Hungary 10 December 1996, Budapest Arbitration Proceedings, CISG-database, available at http://cisgw3.law.pace.edu/cases/961210h1.html.

Malaysia Dairy Industries Pte. Ltd. v. Dairex Holland BV, Netherlands 2 October 1998 District Court 's-Hertogenbosch, available at http://cisgw3.law.pace.edu/cases/981002n1.html.

PPG Industries, Inc. v. Shell Oil Company, 919 F. 2 d. 17 (5 $5^{\text {th }}$ Cir. 1990).

Raw Materials, Inc. v. Manfred Forberich GmbH \& Co., KG, 2004 U.S. Dist. Court [Illinois], July 6, 2004), available at http://cisgw3.law.pace.edu/cases/040706u1.html.

Saltwater isolation tank case, Switzerland 26 April 1995 Commercial Court Zürich, available at: http://cisgw3.law.pace.edu/cases/950426s1.html.

Scafom International BV v. Lorraine Tubes S.A.S, Hof van Cassatie, Belgium, 19 June 2009.

Tradax Export SA v. Andre \& Cie SA, [1976] 1 Lloyd's Rep. 416.

\section{Websites:}

http://www.euro.who.int/en/health-topics/health-emergencies/coronavirus-covid-19/news/ news/2020/3/who-announces-covid-19-outbreak-a-pandemic.

https://www.ilo.org/wcmsp5/groups/public/dgreports/dcomm/documents/briefingnote/ wcms_743146.pdf, visited on 18 May 2020. 